\title{
Effect of effleurage massage versus warm application on shoulder pain among postoperative women with gynecological laparoscopic surgery
}

\author{
Hanan Ibrahim Ibrahim, Wesam Kamal Ali* \\ Obstetric and Gynecologic Nursing, Damanhour University, Damnhour, Egypt
}

Received: May 16, 2019

DOI: $10.5430 /$ jnep.v10n4p51

\author{
Accepted: September 2, 2019 \\ Online Published: January 13, 2020 \\ URL: https://doi.org/10.5430/jnep.v10n4p51
}

\begin{abstract}
Background and objective: Laparoscopic surgery has become a widespread operation for treatment of uncomplicated symptomatic abdominal pathologies. Gynecological laparoscopic procedures are often associated with shoulder pain that may cause more discomfort to the women than the pain at the site of incision. Relive of shoulder pain is an essential goal of gynecological nurse. Its management could be pharmacological or non-pharmacological methods. Among the non-pharmacological approaches are the use of effleurage massage and warm application. The aim of the study was to evaluate the effect of effleurage massage versus warm application on shoulder pain among postoperative women with gynecological laparoscopic surgery.

Methods: Design: A comparative non-randomized controlled clinical trial was utilized in the present study started by the beginning of September 2018 and continued until the end of January 2019. Setting: This study was carried out in the laparoscopic unit at the Elshatby Maternity University Hospital in Alexandria. Subjects: A convenience sample of 80 women who were available at the time of data collection were recruited from the above mentioned setting. Tools: Tool I: Socio-demographic and clinical data structured interview schedule. Tool II: Visual analog scale (VAS), Tool III: physiologic and behavioral response to pain sheet (PBRPS), Tool IV: A modified version of Johansson Pain-o-meter (JPOM).

Results: The study results revealed that shoulder pain intensity was statistically significant before and after intervention among the massage and warm application groups $(p=.000)$. It was also statistically significant between the two groups after intervention $(p=.000)$, where a sizeable proportion of the effleurage massage group (70\%) experienced no pain, compared to only $25 \%$ of the warm application group.

Conclusions: The current study suggests that massage group induces less shoulder pain intensity than the other modality.
\end{abstract}

Key Words: Gynecological laparoscopic surgery, Shoulder pain, Effleurage massage, Warm application

\section{INTRODUCTION}

Laparoscopy is a direct visualization of the peritoneal cavity, ovaries, outside of the tubes, and uterus. A common operation is gynecological laparoscopy. ${ }^{[1]}$ It is associated with introduction of carbon dioxide gas into the abdominal wall, attached through the phrenic nerve to the diaphragm of the shoulder and other body organs. ${ }^{[2]}$
Laparoscopic surgery becomes more appealing and shows many benefits over open surgery, including early recovery, ${ }^{[3,4]}$ a shorter hospital stay, quicker return to daily activity and work and enhanced cosmetic results compared with open operations. ${ }^{[5]}$ Despite these benefits after laparoscopy, many patients experience pain in the shoulder and upper abdomen. Shoulder pain is a prevalent complaint following laparo-

\footnotetext{
* Correspondence: Wesam Kamal Ali; Email: Eng.sameh80@yahoo.com; Address: Obstetric and Gynecologic Nursing, Damanhour University, Damnhour, Egypt.
} 
scopic surgery. The incidence pain of the shoulder ranges from 35 to 80 percent and generally lasts $2-3$ days. ${ }^{[6,7]}$ Sometimes this post-laparoscopic shoulder pain may cause more discomfort to the patient than the pain at the incision site. ${ }^{[8]}$

This shoulder pain may be caused by several variables. In particular, fast peritoneum distention may lead to traumatic traction on blood vessels and nerves with inflammatory mediator release and neuropraxia of the phrenic nerve. ${ }^{[9]}$ Therefore pressure peaks and prolonged insufflations should be avoided ${ }^{[10]}$ Furthermore, the acidotic and cooling impact of insufflated carbon dioxide can damaged the phrenic nerve. This can lead to peritoneum and diaphragm irritation. ${ }^{[11]}$ In addition, post-laparoscopic pain is believed to be caused by carbon dioxide retention in the abdomen, which irritates the phrenic nerve and diaphragm and creates shoulder pain and upper abdomen pain. ${ }^{[12]}$

The literature mentions two promising approaches for reducing post-laparoscopic pain following gynecological surgery. ${ }^{[13]}$ First, pulmonary recruitment maneuvers to open alveoli; which raise intrapulmonary pressure. As a consequence, intraperitoneal pressure will increase and promote the removal from the abdomen of remaining carbon dioxide. ${ }^{[14]}$ Second, the use of intraperitoneal normal saline; Carbon dioxide increases and flows through the port sites by filling the abdomen with warmed normal saline. ${ }^{[15]}$ Normal saline is believed to give an excess carbon dioxide dissolving, which is called a physiologic buffer system. ${ }^{[16]}$ An important correlation was noted between the quantity of remaining pneumoperitoneum and pain scores. It is not evident whether the duration of the surgical procedure has an impact on the post-laparoscopic pain intensity or incidence. ${ }^{[17,18]}$

For the provision of an effective care to these cases updated pharmacological and non-pharmacological approaches are to be followed. Such techniques may help to reduce pain and it must be encouraged as a part of the comprehensive pain management efforts. However, abilities and preferences of the women regarding the use of non-pharmacological methods should be taken into consideration; it should be underlined for the women that these are used together with medical and pharmacological treatments and the use of nonpharmacological methods should be included to the care plan when women is appropriate and willing. ${ }^{[19]}$

Non pharmacologic pain control methods can be used to increase the effect of analgesics, in case of insufficient effect of analgesics, or when analgesics cannot be used. Among non pharmacologic pain control methods are transcutaneous nerve stimulation, application of hot and/or cold compresses, exercises, positioning, and massage. They are physical techniques commonly used in postoperative pain control. While relaxation, distraction, and hypnosis are cognitive/behavioral techniques. ${ }^{[20]}$ Massage is defined as the manipulations of the soft tissues; these manipulations are most efficiently performed with palmer aspect of the hand and administered for the purpose of producing effects on the nervous system as well as on the local and the general circulation of blood and lymph. ${ }^{[21,22]}$

Massage may be used as a primary therapeutic intervention or as an adjunct to other therapeutic techniques. Uses can include the following: Mobilization of intertissue fluids, reduction of edema, increase of local blood flow, decrease of muscle soreness and stiffness, moderation of pain, facilitation of relaxation and prevention or elimination of adhesions. ${ }^{[23]}$

Effleurage as a form of therapeutic massage has been used for the management of pain. ${ }^{[24]}$ Effleurage comes from the French word effleurer (to touch lightly. It is sliding or gliding strokes over the body with a continuous motion. Gliding, stripping, broadening and stroking are the common terms used to define the technique. ${ }^{[25]}$ Effleurage is a light fingertip massage. ${ }^{[26]}$ The technique is accomplished with the fingertips, thumb, palm of the hand and forearm. The palm works on the large surface e.g. face, back, abdomen, shoulder, neck and arm while the fingertips work on the small surface such as around the eye, hands and any other small area. ${ }^{[27,28]}$

A very significant effect of the effleurage massage is reduction of pain through the mechanism of neurological (gatecontrol theory) by activating the neural-gating mechanism in the spinal cord. Where the tactile information from massage might stimulate larger, fast nerve fibers and then, block the smaller, slower nerve fibers that detect pain. This effect, presumably results from local lateral inhibition in the spinal cord. Massage can also increase biochemical substances such as serotonin, which is a neurotransmitter that plays a role in reducing pain. ${ }^{[29]}$

An application of heat, in various forms, is a popular pain relieving strategy. It is easy to use, inexpensive, require no prior practice, and have minimal negative side effects when used properly. Although there are no randomized controlled clinical trials on the use of heat for relieving shoulder pain, these modalities have been studied for their effects on pain induced under experimental conditions. Heat sources include a hot water bottle, heated rice-filled sock, warm compress (wash clothes soaked in warm water and wrung out), electric heating pad, warm blanket, and warm bath or shower. In addition to being used for pain relief, heat is also used to relieve chills or trembling, decrease joint stiffness, reduce muscle spasm, and increase connective tissue extensibility. ${ }^{[30]}$

Generally, Evidence-Based (EB) nursing care uses the best 
available research on the safety and effectiveness of specific practice to help guide nursing care decisions and to facilitate optimal out-come . Although the field of gynecological laparoscopic surgery pioneered Evidence- Based Practice (EBP), resulting in a wealth of clear guidance of EB nursing care, there remains widespread and continuing underuse of beneficial practices. Among these practices is the relief of pain - which is the major focus of pain management - by the use of simple non-pharmacological modalities. ${ }^{[31]}$

\subsection{Significance of the study}

The gynecological laparoscopic surgery has been successfully introduced into practice as; this minimally invasive surgery is associated with low morbidity. Frequency of pain after laparoscopic surgery varies from $35.0 \%$ to $80.0 \%$ (6). Reducing this pain to the level, which narcotic analgesic is no longer required is an important step towards performing laparoscopy as a day case procedure and enhancing women's recovery. Moreover, because of the exact mechanism of post laparoscopic shoulder pain (PLSP) remains unclear, ${ }^{[32]}$ so, the aim of the present study was to evaluate the effect of effleurage massage versus warm application on shoulder pain among postoperative women with gynecological laparoscopic surgery.

\subsection{Aim}

The aim of the study was to evaluate the effect of effleurage massage versus warm application on shoulder pain among postoperative women with gynecological laparoscopic surgery.

\subsection{Research hypotheses}

1) Postoperative women with gynecological laparoscopic surgery who receive effleurage massage exhibit less shoulder pain intensity than those who receive warm application.

2) Postoperative women with gynecological laparoscopic surgery who receive warm application exhibit less shoulder pain intensity than those who receive massage.

\section{MATERIALS AND METHOD}

\subsection{Research design}

A comparative non-randomized controlled clinical trial was utilized.

\subsection{Setting}

This study was carried out in the laparoscopic unit at the Elshatby Maternity University Hospital in Alexandria. This setting was chosen since it is an educational hospital where the interventions needed can be employed with sufficient staff cooperation and without real obstacles.

Published by Sciedu Press

\subsection{Subjects}

The Epi-Info program was used to estimate the sample size using the following parameters:

1) Target population 1,200 per 3 months.

2) Expected frequency $=50 \%$

3) Accepted error $=5 \%$.

4) Confidence coefficient $=95 \%$.

5) Sample size $=80$.

Accordingly a convenience sample of 80 women who were available at the time of data collection were recruited from the above mentioned setting. The subjects were selected by using the non-probability sampling technique according to the following inclusion criteria:

The inclusion criteria included:

- Free from any medical or gynecological risk factors such as, morbid obese (BMI > 45). Medical history of appendicitis, rupture of ectopic pregnancy, rupture of an ovarian cyst, and pelvic inflammatory disease.

- Willing to participate in the study.

The subjects were equally divided into two groups as follows:

Study group 1: The massage group which included 40 participants.

Study group 2: The warm compresses group which included the other 40 participants.

\section{Tools:}

Four tools were used for collecting the necessary data.

Tool I: Structured Interview Schedule, it include the two parts:

This tool was developed and used by the researcher to elicit the basic data as follows:

-Part one: Biosocio-demographic data, including: age, level of education, occupation, current residence and body mass index.

-Part two: Clinical data of reproductive and menstrual history including:-gravidity, parity, number of abortion, age at menarche, amount, duration, rhythm and etc.

Tool II: Visual analog scale (VAS). This tool was originally developed by Melzack and Katz (1994). ${ }^{[33]}$ It is a self-report device for measuring pain intensity. It was adopted and translated into the Arabic language to suit the Egyptian culture. It consists of a horizontal line used for subjective estimation of the patient's pain. It comprises a 10 point numerical scale, corresponding to the degree of pain with zero representing no pain and 10 representing the worst degree of pain. In between these two opposite ends, words as mild, moderate, severe and unbearable are assigned to each $2 \mathrm{~cm}$ distance, 
respectively.

Tool III: Physiologic and behavioral response to pain sheet (PBRPS). It was originally developed by Hanken (1996) ${ }^{[34]}$ and Chamber Price (1967) ${ }^{[35]}$ to measure physiological and behavioral pain responses. It entails two parts:

Part 1-Physiological response:- it was originally developed by Hanken (1996) in order to measure the physiological response to pain. It was adopted, translated and used by the researcher it included:

1) Vital signs and blood pressure.

2) Gastro-intestinal tract response such as nausea and vomiting.

3) Skin response such as: flushing and diaphoresis.

Part 2-Behavioral response (A modified version of Chamber Price Pain Rating Scale (CPPRS) for measuring quality of pain. It was originally developed by Chamber and Price (1967). It is used to measure the behavioral response to pain. It includes four dimensions: posture, gross motor activity, facial expression and verbalization. For each of these four major behavioral responses one of three alternative choices were elicited by the researcher. For posture, the choice is between relaxed or guarded or tense posture. For gross motor activity, the choice is between quiet, slightly restless and restless. For facial expression the choice is between no frowning, some frowning and constant frowning or grimacing. Finally, for verbalization the choice is between normal no sound, groans/moans and cries/sobs.

Each of the 12 alternatives was scored as either absent (0), (1) for mild or (2) for severe. The total score ranges from 0-24. Statistically, this score was translated to the corresponding pain intensity as follows:

- No pain (0)

- Mild pain (1-6)

- Moderate pain (7-12)

- Sever pain (13-18)

- Unbearable pain $(\geq 19)$.

Tool IV: A modified version of Johansson Pain-o-meter (JPOM) This tool was originally developed and validated by Johansson (1973). ${ }^{[36]}$ Then after, adopted, translated and used by the researcher. It was used to assess the intensity of sensory and affective component of pain (pain quality) by calculating the total parturient choice of words after translating it into Arabic language. It is composed of 11 affective and 12 sensory pain word descriptors. Affective pain words were rated as follows: torturing(5), killing (5), suffocating (5), terrifying (5), dreadful (4), fearful(4), troublesome (3), tiring (3), irritating (2), nagging (1) and happy (0). While sensory pain words were rated as follows: cutting(5), tearing (5), sharp(5), burning (4), cramping (4), pressing (4), aching (4), gnawing (3), pinching (3), stinging (2), pricking (2) and sore (1).

The total parturient choice of words was calculated to determine pain intensity. A pain rating index rank (PRIR) was used, based on accumulation of numerical values assigned to the chosen words.

The PRIR were scored as follows:

- (0) no pain

- 1-3 representing mild pain

- 4-6 representing moderate pain

- 7-10 representing sever pain

- More than 10 representing intolerable pain

\subsection{Procedures}

Then the study was executed according to the following steps:

\section{Ethical considerations}

For each recruited subject the following issues were considered: Securing the subject's informed consent, keeping the subject's privacy, assuring the subjects data confidentiality, and the right to withdraw at any time.

\section{Approvals}

An official letter from the Faculty of Nursing, University of Damanhour was directed to the responsible authorities to obtain their permission to conduct the study after explaining its purpose.

\section{Tools}

- Tool (I) was developed by the researcher after extensive review of recent and relevant literature.

- Tools III, IV were adopted, translated into Arabic language and tested for content validity by a jury of five experts in the field.

\section{Tool's reliability}

Tools reliability was tested using Cronbach's Alpha test (internal consistency). Its result was 0.80 which indicates a satisfactory and accepted reliability of the tool.

\section{Consent}

Each woman was individually interviewed and informed about the aim of the study in order to obtain her informed consent to participate in the study. Again, each of those who agreed to take part in the study was assured about confidentiality, privacy and right to withdraw at any time.

\section{Pilot study}

A pilot study was carried out on 10 women (who were 
excluded from the main study sample) and the necessary changes were undertaken. The main purposes of the pilot study were to ascertain clarity, relevance and the applicability of the tools, detect any problem peculiar to the statements as a sequence and clarity that might interfere with the process of data collection, as well as estimate the time needed to complete the sheet. Results of the pilot study were the tools were clear, relevant, and applicable and no changes were made, no problem that interfered with the process of data collection was detected, and each interview took approximately fifteen to twenty minutes.

\section{Data collection (procedure)}

\section{Assessment}

Collection of data covered a period of 5 months (September 2018 and continued until the end of January 2019) Each woman in the two groups was individually interviewed during the preoperative period to collect socio-demographic and clinical data using tool I. Tools II, III and $1 \mathrm{~V}$ were used to assess pain intensity, physiological and behavioral and quality of pain responses.

\section{Planning and implementation}

The subjects were assigned to one of 2 groups as follows: Group1which comprised 40 women upon whom shoulder massage was applied by the researcher after four hours postoperatively. The massage was done for a total of 30 minutes.

Group 2 which comprised 40 women upon whom warm water bag $\left(38^{\circ} \mathrm{C}-40^{\circ} \mathrm{C}\right)$ was applied on the shoulder after four hours postoperatively. The warm water was done for a total of 30 minutes.

\section{Evaluation}

Pain states were evaluated for both groups immediately after intervention using tool II (pain intensity), tool III (physiological and behavioral response to pain) and tool IV (quality of pain).Comparison between the two groups was made to determine which intervention induces less shoulder pain.

\subsection{Statistical analysis}

Statistical analysis was done by the researcher after collection of data by using statistical package for social science (SPSS) version 16 program. The collected data was categorized, coded, computerized, tabulated and analyzed. A descriptive and analytical statistics were used as frequency distribution tables, percentage, means and standard deviations. Chi-square-test, Fisher Exact test, $T$-test and One-Way ANOVA test at .05 levels to find out the statistical significant difference of the results.

Limitations of the study: Pain score was limited evaluated at different time, because the women were discharged from the hospital at the same day of operation (5hrs after operation).

\section{Results}

As shown in Table 1, $60.0 \%$ of the massage and warm application groups were aged $20-<35$ years. Illiteracy was evident among $(45 \% \& 35 \%)$ of the massage and warm application groups, respectively. However, $35 \%$ \& $25 \%$ of them respectively had secondary level of education or its equivalence. The majority of the massage and warm application groups (85\%) were housewives. About one-half (55\%) of the massage group were rural residents, compared to only $35 \%$ of the warm application group. BMI indicated that an equal percent $(60 \%)$ of the massage and warm application groups had normal weight. No statistically significant differences were found between the two groups' socio-demographic characteristics.

According to Table 2, it was observed that the age at menarche was $11-<16$ years among $100 \% \& 95 \%$ of the warm application and massage groups, respectively. A sizeable proportion of them $(75 \% \& 65 \%)$ respectively had regular menstruation. Amount of menses was moderate among $70 \%$ $\& 65 \%$ of the massage and warm application groups, respectively.

Duration of menstruation was 3-5 days as reported by $70 \%$ $\& 75 \%$ of the massage and warm application groups respectively. Interval of menstruation was 21-35 days among $75 \%$ of the warm application group, compared to $60 \%$ of the massage group. The relationship between the two groups' menstrual history was not statistically significant, except for interval of menstruation $(p=.036)$

Table 3 shows the reproductive history of the study subjects. It was obvious that $55 \% \& 60 \%$ of the massage and warm application groups respectively, were nulligravida. Where, $80 \% \& 75 \%$ of the massage and warm application groups, respectively, were nullipara. An equal percent (70\%) of the massage and warm application groups had no abortion. No statistically significant difference was detected between the two groups' reproductive history.

Table 4 demonstrates the laparoscopic data of the study subjects. It reveals that $60 \% \& 50 \%$ of the massage and warm application groups, respectively, came for diagnostic laparoscope, while $40 \% \& 50 \%$ of them, respectively, came for curative laparoscope. The duration of laparoscope was 30 to less than 45 minutes among $45 \%$ \& $40 \%$ of the massage and warm application groups, respectively. The site of pain was in both shoulders among $55 \%$ of the massage group, compared to $30 \%$ of the warm application group. In contrast, it was in the right shoulder among $60 \%$ of the latter group, compared to 30 of the former group. The Breathing was reported as a factor of increasing pain among $60 \%$ of the massage group, compared to $35 \%$ of the warm application 
group. Slightly more than one-half (55\%)of the massage and analgesics. The relationship between the two groups' laparowarm application groups reported no factors of decreasing scopic data was not statistically significant, except for site of pain, while $35 \%$ of them reported walking and $10 \%$ reported pain $(p=.025)$.

Table 1. Number and percent distribution of the study subjects according to their socio-demographic characteristics

\begin{tabular}{|c|c|c|c|c|c|}
\hline \multirow[t]{2}{*}{ Socio-demographic characteristics } & \multicolumn{2}{|c|}{$\begin{array}{l}\text { G1 (40) } \\
\text { (Massage group) }\end{array}$} & \multicolumn{2}{|c|}{$\begin{array}{l}\text { G } 2(40) \\
\text { (Warm application group) }\end{array}$} & \multirow[t]{2}{*}{$\mathbf{F} / \chi^{2}(P)$} \\
\hline & $\mathbf{N}$ & $\%$ & $\mathbf{N}$ & $\%$ & \\
\hline \multicolumn{6}{|l|}{ Age (years): } \\
\hline $18-$ & 4 & 10.00 & 2 & 05.00 & \multirow{3}{*}{$\begin{array}{l}0.821 \\
(.663)\end{array}$} \\
\hline $20-$ & 24 & 60.00 & 24 & 60.00 & \\
\hline $35-48$ & 12 & 30.00 & 14 & 35.00 & \\
\hline \multicolumn{6}{|l|}{ Level of Education: } \\
\hline Illiterate/Read \& Write & 18 & 45.00 & 14 & 35.00 & \multirow{4}{*}{$\begin{array}{l}3.833 \\
(.280)\end{array}$} \\
\hline Primary \&Preparatory & 8 & 20.00 & 4 & 10.00 & \\
\hline Secondary or its equivalence & 10 & 25.00 & 14 & 35.00 & \\
\hline University or higher & 4 & 10.00 & 8 & 20.00 & \\
\hline \multicolumn{6}{|l|}{ Occupation: } \\
\hline Housewife & 34 & 85.00 & 34 & 85.00 & 0.000 \\
\hline Working & 6 & 15.00 & 6 & 15.00 & 1.000 \\
\hline \multicolumn{6}{|l|}{ Current Residence: } \\
\hline Rural & 22 & 55.00 & 14 & 35.00 & 3.232 \\
\hline Urban & 18 & 45.00 & 26 & 65.00 & $(.072)$ \\
\hline \multicolumn{6}{|l|}{ BMI: } \\
\hline Underweight $(16-<18.5)$ & 6 & 15.00 & 2 & 05.00 & \multirow{5}{*}{$\begin{array}{l}6.000 \\
(.199)\end{array}$} \\
\hline Normal weight $(18.5-<25)$ & 24 & 60.00 & 24 & 60.00 & \\
\hline Overweight $(25-<30)$ & 10 & 25.00 & 10 & 25.00 & \\
\hline Grade 1 Obesity $(30-<35)$ & 0 & 00.00 & 2 & 05.00 & \\
\hline Grade 3 Obesity $(>40)$ & 0 & 00.00 & 2 & 05.00 & \\
\hline
\end{tabular}

Table 2. Number and percent distribution of the study subjects according to their menstrual history

\begin{tabular}{|c|c|c|c|c|c|}
\hline \multirow[t]{2}{*}{ Menstrual history } & \multicolumn{2}{|c|}{$\begin{array}{l}\text { G1 (40) } \\
\text { (Massage group) }\end{array}$} & \multicolumn{2}{|c|}{$\begin{array}{l}\text { G } 2 \text { (40) } \\
\text { (Warm application group) }\end{array}$} & \multirow[t]{2}{*}{$\mathbf{F} / \chi^{2}(P)$} \\
\hline & $\mathbf{N}$ & $\%$ & $\mathbf{N}$ & $\%$ & \\
\hline \multicolumn{6}{|c|}{ Age at Menarche (years): } \\
\hline $11-<16$ & 38 & 95.00 & 40 & 100.00 & 2.051 \\
\hline$\geq 16$ & 2 & 05.00 & 0 & 00.00 & $(.152)$ \\
\hline \multicolumn{6}{|l|}{ Frequency: } \\
\hline Regular & 26 & 65.00 & 30 & 75.00 & 0.952 \\
\hline Irregular: & 14 & 35.00 & 10 & 25.00 & $(.329)$ \\
\hline \multicolumn{6}{|l|}{ Amount: } \\
\hline Scanty $(>10 \mathrm{ml})$ & 0 & 00.00 & 2 & 05.00 & \multirow{3}{*}{$\begin{array}{l}2.074 \\
(.355)\end{array}$} \\
\hline Moderate $(10-120 \mathrm{ml})$ & 28 & 70.00 & 26 & 65.00 & \\
\hline Profuse $(>120 \mathrm{ml})$ & 12 & 30.00 & 12 & 30.00 & \\
\hline \multicolumn{6}{|l|}{ Duration (days): } \\
\hline $3-5$ & 28 & 70.00 & 30 & 75.00 & \multirow{2}{*}{$\begin{array}{l}0.251 \\
(.616)\end{array}$} \\
\hline$>5$ & 12 & 30.00 & 10 & 25.00 & \\
\hline \multicolumn{6}{|l|}{ Interval: } \\
\hline$<21$ & 6 & 15.00 & 0 & 00.00 & \multirow{3}{*}{$\begin{array}{l}6.667 \\
(.036)^{*}\end{array}$} \\
\hline $21-35$ & 24 & 60.00 & 30 & 75.00 & \\
\hline$>35$ & 10 & 25.00 & 10 & 25.00 & \\
\hline
\end{tabular}

Note. $\chi^{2}(P)$ : Chi-Square Test $\& P$ for $\chi^{2}$ Test; F(P):Fisher Exact test $\& P$ for F Test; ${ }^{*}$ : Significant at $p \leq .05$. 
Table 3. Number and percent distribution of the study subjects according to their reproductive history

\begin{tabular}{|c|c|c|c|c|c|}
\hline \multirow[t]{2}{*}{ Reproductive history } & \multicolumn{2}{|c|}{$\begin{array}{l}\text { G1 (40) } \\
\text { (Massage group) }\end{array}$} & \multicolumn{2}{|c|}{$\begin{array}{l}\text { G } 2(40) \\
\text { (Warm application group) }\end{array}$} & \multirow[t]{2}{*}{$\mathbf{F} / \chi^{2}(\mathbf{P})$} \\
\hline & $\mathbf{N}$ & $\%$ & $\mathbf{N}$ & $\%$ & \\
\hline \multicolumn{6}{|l|}{ Gravidity: } \\
\hline 0 & 22 & 55.00 & 24 & 60.00 & \multirow{3}{*}{$\begin{array}{l}0.22 \\
(.896)\end{array}$} \\
\hline $1-3$ & 16 & 40.00 & 14 & 35.00 & \\
\hline $5-7$ & 2 & 05.00 & 2 & 05.00 & \\
\hline \multicolumn{5}{|l|}{ Parity: } & \multirow{3}{*}{$\begin{array}{l}0.287 \\
(.592)\end{array}$} \\
\hline 0 & 32 & 80.00 & 30 & 75.00 & \\
\hline $1-3$ & 8 & 20.00 & 10 & 25.00 & \\
\hline \multicolumn{6}{|l|}{ Abortion: } \\
\hline 0 & 28 & 70.00 & 28 & 70.00 & \multirow{3}{*}{$\begin{array}{l}4.8 \\
(.091)\end{array}$} \\
\hline $1-2$ & 8 & 20.00 & 12 & 30.00 & \\
\hline $3-4$ & 4 & 10.00 & 0 & 00.00 & \\
\hline
\end{tabular}

Note. $\chi^{2}(P)$ : Chi-Square Test $\& P$ for $\chi^{2}$ Test; $\mathrm{F}(P)$ :Fisher Exact test $\& P$ for $\mathrm{F}$ Test; $*$ : Significant at $p \leq .05$.

Table 4. Number and percent distribution of the study subjects according to their laparoscopic data

\begin{tabular}{|c|c|c|c|c|c|}
\hline \multirow[t]{2}{*}{ Labaroscpic data } & \multicolumn{2}{|c|}{$\begin{array}{l}\text { G1 (40) } \\
\text { (Massage group) }\end{array}$} & \multicolumn{2}{|c|}{$\begin{array}{l}\text { G } 2 \text { (40) } \\
\text { (Warm application group) }\end{array}$} & \multirow[t]{2}{*}{$\mathbf{F} / \chi^{2}(\mathbf{P})$} \\
\hline & $\mathbf{N}$ & $\%$ & $\mathbf{N}$ & $\%$ & \\
\hline \multicolumn{6}{|l|}{ Causes: } \\
\hline Diagnostic & 24 & 60.00 & 20 & 50.00 & \multirow{2}{*}{$\begin{array}{l}0.808 \\
(.369)\end{array}$} \\
\hline Curative & 16 & 40.00 & 20 & 50.00 & \\
\hline \multicolumn{6}{|l|}{ Duration (minutes): } \\
\hline $15-$ & 14 & 35.00 & 18 & 45.00 & \multirow{3}{*}{$\begin{array}{l}0.903 \\
(.637)\end{array}$} \\
\hline $30-$ & 18 & 45.00 & 16 & 40.00 & \\
\hline $45-60$ & 8 & 20.00 & 6 & 15.00 & \\
\hline \multicolumn{6}{|l|}{ Site of pain: } \\
\hline Rt shoulder & 12 & 30.00 & 24 & 60.00 & \multirow{3}{*}{$\begin{array}{l}7.341 \\
(.025)^{*}\end{array}$} \\
\hline Lt shoulder & 6 & 15.00 & 4 & 10.00 & \\
\hline Both & 22 & 55.00 & 12 & 30.00 & \\
\hline \multicolumn{6}{|c|}{ Factors increasing pain: } \\
\hline None & 12 & 30.00 & 20 & 50.00 & \multirow{4}{*}{$\begin{array}{l}6.632 \\
(.085)\end{array}$} \\
\hline Eating & 0 & 00.00 & 2 & 05.00 & \\
\hline Drinking & 4 & 10.00 & 4 & 10.00 & \\
\hline Breathing & 24 & 60.00 & 14 & 35.00 & \\
\hline \multicolumn{6}{|c|}{ Factors decreasing pain: } \\
\hline None & 22 & 55.00 & 22 & 55.00 & \multirow{3}{*}{$\begin{array}{l}0.000 \\
(1.000)\end{array}$} \\
\hline Walking & 14 & 35.00 & 14 & 35.00 & \\
\hline Analgesics & 4 & 10.00 & 4 & 10.00 & \\
\hline
\end{tabular}

Note. $\chi^{2}(P)$ : Chi-Square Test $\& P$ for $\chi^{2}$ Test; F $(P)$ :Fisher Exact test $\& P$ for F Test; ${ }^{*}$ : Significant at $p \leq .05$.

Table 5 clarifies the study subjects' pain intensity according to visual analoge scale. It was statistically difference before and after intervention among both groups $(p=.000)$, where it was relieved after intervention among $70 \% \& 25 \%$ of them, respectively. It was also statistically significant between the two groups after intervention $(p=.000)$, where a sizeable proportion of the massage group (70\%) experienced no pain, compared to only $25 \%$ of the warm application group.

Table 6 manifests the study subjects' mean vital signs. The mean temperature reveals statistically significant differences $(p \leq .0001 \& p=.002)$ among the massage and warm application groups respectively, where it had a higher mean after intervention than before intervention. However, the relationship between the two groups was not statistically significant before and after intervention.

In addition, the mean pulse displays a statistically significant differences between the massage and warm application groups before and after intervention $(p=.001 \& p=.002)$ 
respectively, where it was $90.55 \pm 8.092 \& 88.7 \pm 6.227$ group, compared to $84.8 \pm 6.505 \& 83.9 \pm 7.175$ respecbefore and after intervention respectively among the former tively among the latter group.

Table 5. Number and percent distribution of the study subjects according to their intensity of pain using visual analoge scale

\begin{tabular}{|c|c|c|c|c|c|c|c|c|c|}
\hline \multirow{3}{*}{$\begin{array}{l}\text { Intensity of } \\
\text { pain }\end{array}$} & \multicolumn{4}{|c|}{ G1 (40) (Massage group) } & \multicolumn{4}{|c|}{ G 2 (40) (Warm application group) } & \multirow{3}{*}{$\mathbf{F} / \chi^{2}(P)$} \\
\hline & \multicolumn{2}{|c|}{$\begin{array}{l}4 \text { hrs after operation } \\
\& \text { before intervention }\end{array}$} & \multicolumn{2}{|c|}{$\begin{array}{l}6 \text { hrs after operation } \\
\& \text { after intervention }\end{array}$} & \multicolumn{2}{|c|}{$\begin{array}{l}4 \text { hrs after operation } \\
\text { \& before intervention }\end{array}$} & \multicolumn{2}{|c|}{$\begin{array}{l}6 \text { hrs after operation } \\
\& \text { after intervention }\end{array}$} & \\
\hline & $\mathbf{N}$ & $\%$ & $\mathbf{N}$ & $\%$ & $\mathbf{N}$ & $\%$ & $\mathbf{N}$ & $\%$ & \\
\hline None & 0 & 00.00 & 28 & 70.00 & 0 & 00.00 & 10 & 25.00 & \multirow{4}{*}{$\begin{array}{l}\text { Before } \\
\text { intervention } \\
4.659 \\
(.199) \\
\text { After } \\
\text { intervention }\end{array}$} \\
\hline Mild & 2 & 05.00 & 8 & 20.00 & 0 & 00.00 & 18 & 45.00 & \\
\hline Moderate & 16 & 40.00 & 4 & 10.00 & 24 & 60.00 & 12 & 30.00 & \\
\hline Strong & 20 & 50.00 & 0 & 00.00 & 14 & 35.00 & 0 & 00.00 & \\
\hline Unbearable & 2 & 05.00 & 0 & 00.00 & 2 & 05.00 & 0 & 00.00 & $\begin{array}{l}16.372 \\
(.000)^{*}\end{array}$ \\
\hline $\mathrm{F} / \chi^{2}(P)$ & \multicolumn{4}{|c|}{$60.8(.000)^{*}$} & \multicolumn{4}{|c|}{$48(.000)^{*}$} & \\
\hline
\end{tabular}

Note. $\chi^{2}(P)$ : Chi-Square Test $\& P$ for $\chi^{2}$ Test; F $(P)$ :Fisher Exact test $\& P$ for F Test; $*$ : Significant at $p \leq .05$.

Table 6. Distribution of the study subjects according to their mean vital signs

\begin{tabular}{|c|c|c|c|c|c|}
\hline \multirow{3}{*}{ Vital signs } & \multicolumn{2}{|l|}{ G1 (40) (Massage group) } & \multicolumn{2}{|c|}{ G 2 (40) (Warm application group) } & \multirow{3}{*}{$T$ test/ $(P)$} \\
\hline & $\begin{array}{l}4 \text { hrs after operation } \\
\text { \& before intervention }\end{array}$ & $\begin{array}{l}6 \text { hrs after operation } \\
\& \text { after intervention }\end{array}$ & $\begin{array}{l}4 \text { hrs after operation } \\
\text { \& before intervention }\end{array}$ & $\begin{array}{l}6 \text { hrs after operation } \\
\text { \& after intervention }\end{array}$ & \\
\hline & Mean \& SD & Mean \& SD & Mean \& SD & Mean \& SD & \\
\hline Temperature & $36.775 \pm 0.252$ & $36.975 \pm 0.110$ & $36.85 \pm 0.282$ & $37.01 \pm 0.139$ & $\begin{array}{l}\text { Before } \\
1.254(.214) \\
\text { After } \\
1.249(.216)\end{array}$ \\
\hline$T$ test $/(P)$ & $4.600(<.0001)^{*}$ & & $3.219(.002)^{*}$ & & \\
\hline Pulse & $90.55 \pm 8.092$ & $88.7 \pm 6.227$ & $84.8 \pm 6.505$ & $83.9 \pm 7.175$ & $\begin{array}{l}\text { Before } \\
3.503(.001)^{*} \\
\text { After } \\
3.196(.002)^{*}\end{array}$ \\
\hline$T$ test $/(P)$ & $1.146(.255)$ & & $0.588(.558)$ & & \\
\hline Systolic BP & $108.5 \pm 7.355$ & $113 \pm 7.232$ & $111.5 \pm 6.622$ & $113 \pm 8.533$ & $\begin{array}{l}\text { Before } \\
1.917(.059) \\
\text { After } \\
0.000(1.000)\end{array}$ \\
\hline$T$ test $/(P)$ & $2.759(.007)^{*}$ & & $0.878(.383)$ & & \\
\hline Diastolic BP & $71.5 \pm 5.57$ & $74.5 \pm 5.97$ & $70 \pm 7.845$ & $77.1 \pm 5.71$ & $\begin{array}{l}\text { Before } \\
0.986(.327) \\
\text { After } \\
1.991(.050)^{*}\end{array}$ \\
\hline$T$ test $/(P)$ & $2.324(.023)^{*}$ & & $4.628(<.0001)^{*}$ & & \\
\hline Respiration & $20.4 \pm 2.03$ & $20.85 \pm 1.075$ & $19.1 \pm 1.751$ & $20.4 \pm 1.374$ & $\begin{array}{l}\text { Before } \\
3.062(.003)^{*} \\
\text { After } \\
1.31(.107)\end{array}$ \\
\hline$T$ test/ $(P)$ & $1.236(.220)$ & & $3.694(.000)^{*}$ & & \\
\hline
\end{tabular}

Note. $(P)$ for $t$ test; *: Significant at $p \leq .05$

Moreover, the mean systolic BP exhibits a statistically significant difference among the massage group before and after intervention $(p \leq .007)$, where it was higher after intervention than before intervention. Furthermore, the mean diastolic
BP elucidates statistically significant differences among the warm application and massage groups $(p \leq .0001 \& p=$ .023) respectively before and after intervention, where it was higher among them after intervention than before interven- 
tion. The mean diastolic BP was also statistically significant between the massage and warm application groups after intervention $(p=.050)$, where it was higher among the latter group than the former one.

Finally, the mean respiration demonstrates a statistically significant difference among the warm application group before and after intervention $(p=.000)$, where it was higher after intervention than before intervention. It also manifests a statistically significant difference between the massage and warm application groups before intervention $(p=.003)$, where it was higher among the former group than the latter one.

Table 7 elucidates the study subjects' intensity of pain according to physiological and behavioral pain response. It was observed that pain intensity was statistically significant before and after intervention among the massage and warm application groups $(p=.000)$, where it was relieved after intervention among $55 \% \& 20 \%$ of them respectively. It was also statistically significant between the two groups after intervention ( $p=.007)$, where a more than two-quarters $(55 \%)$ of the massage group experienced no pain, compared to less than one-quarter $(20 \%)$ of the warm application group.

Table 8 exhibits the study subjects' intensity of pain according to sensory pain response. It was found that pain intensity was statistically significant before and after intervention among the both groups $(p=.000)$, where it was relieved after intervention among $65 \% \& 15 \%$ of them respectively. It was also statistically significant between the two groups before intervention $(p=.054)$, where $60 \%$ of the massage group experienced strong pain, compared to $35 \%$ of the warm application group. Additionally, pain intensity was statistically significant between the two groups after intervention ( $p=.000)$, where more than three-fifths $(65 \%)$ of the former group experienced no pain, compared to less than one-fifth $(15 \%)$ of the latter group.

Table 7. Number and percent distribution of the study subjects according to their intensity of pain using physiological and behavioral pain response

\begin{tabular}{|c|c|c|c|c|c|c|c|c|c|}
\hline \multirow{3}{*}{$\begin{array}{l}\text { Intensity } \\
\text { of pain }\end{array}$} & \multicolumn{4}{|c|}{ G1 (40) (Massage group) } & \multicolumn{4}{|c|}{ G 2 (40) (Warm application group) } & \multirow{3}{*}{$F / \chi^{2}(p)$} \\
\hline & \multicolumn{2}{|c|}{$\begin{array}{l}4 \text { hrs after operation \& } \\
\text { before intervention }\end{array}$} & \multicolumn{2}{|c|}{$\begin{array}{l}6 \text { hrs after operation } \\
\& \text { after intervention }\end{array}$} & \multicolumn{2}{|c|}{$\begin{array}{l}4 \text { hrs after operation \& } \\
\text { before intervention }\end{array}$} & \multicolumn{2}{|c|}{$\begin{array}{l}6 \text { hrs after operation } \\
\& \text { after intervention }\end{array}$} & \\
\hline & $\mathbf{N}$ & $\%$ & $\mathbf{N}$ & $\%$ & $\mathbf{N}$ & $\%$ & $\mathbf{N}$ & $\%$ & \\
\hline None & 0 & 00.00 & 22 & 55.00 & 0 & 00.00 & 8 & 20.00 & \multirow{6}{*}{$\begin{array}{l}\text { Before } \\
\text { intervention } \\
4.635 \\
(.327) \\
\text { After } \\
\text { intervention } \\
13.867 \\
(.007)^{*}\end{array}$} \\
\hline Mild & 0 & 00.00 & 14 & 35.00 & 0 & 00.00 & 16 & 40.00 & \\
\hline Moderate & 18 & 45.00 & 4 & 10.00 & 24 & 60.00 & 16 & 40.00 & \\
\hline Strong & 22 & 55.00 & 0 & 00.00 & 14 & 35.00 & 0 & 00.00 & \\
\hline Unbearable & 0 & 00.00 & 0 & 00.00 & 2 & 05.00 & 0 & 00.00 & \\
\hline $\mathrm{F} / \chi^{2}(p)$ & \multicolumn{4}{|c|}{$66.909(0.000)^{*}$} & \multicolumn{4}{|c|}{$41.6(0.000)^{*}$} & \\
\hline
\end{tabular}

Note. $\chi^{2}(P)$ : Chi-Square Test \& $P$ for $\chi^{2}$ Test; $\mathrm{F}(P)$ :Fisher Exact test \& $P$ for F Test; $;$ : Significant at $p \leq .05$.

Table 8. Number and percent distribution of the study subjects according to their intensity of pain using sensory pain response

\begin{tabular}{|c|c|c|c|c|c|c|c|c|c|}
\hline \multirow{3}{*}{$\begin{array}{l}\text { Intensity of } \\
\text { pain }\end{array}$} & \multicolumn{4}{|c|}{ G1 (40) (Massage group) } & \multicolumn{4}{|c|}{ G 2 (40) (Warm application group) } & \multirow{3}{*}{$\mathbf{F} / \chi^{2}(P)$} \\
\hline & \multicolumn{2}{|c|}{$\begin{array}{l}4 \mathrm{hrs} \text { after operation } \\
\text { \& before intervention }\end{array}$} & \multicolumn{2}{|c|}{$\begin{array}{l}6 \text { hrs after operation } \\
\& \text { after intervention }\end{array}$} & \multicolumn{2}{|c|}{$\begin{array}{l}4 \mathrm{hrs} \text { after operation } \\
\text { \& before intervention }\end{array}$} & \multicolumn{2}{|c|}{$\begin{array}{l}6 \text { hrs after operation } \\
\& \text { after intervention }\end{array}$} & \\
\hline & $\mathbf{N}$ & $\%$ & $\mathbf{N}$ & $\%$ & $\mathbf{N}$ & $\%$ & $\mathbf{N}$ & $\%$ & \\
\hline None & 0 & 00.00 & 26 & 65.00 & 0 & 00.00 & 6 & 15.00 & Before \\
\hline Mild & 2 & 05.00 & 10 & 25.00 & 0 & 00.00 & 20 & 50.00 & intervention \\
\hline Moderate & 14 & 35.00 & 4 & 10.00 & 24 & 60.00 & 14 & 35.00 & $9.263(.054)^{*}$ \\
\hline Strong & 24 & 60.00 & 0 & 00.00 & 14 & 35.00 & 0 & 00.00 & $\begin{array}{l}\text { After } \\
\text { intervention }\end{array}$ \\
\hline Unbearable & 0 & 00.00 & 0 & 00.00 & 2 & 05.00 & 0 & 00.00 & $21.389(.000)^{*}$ \\
\hline $\mathrm{F} / \chi^{2}(P)$ & \multicolumn{4}{|c|}{$60.889(.000)^{*}$} & \multicolumn{4}{|c|}{$44.632(.000)^{*}$} & \\
\hline
\end{tabular}

Table 9 displays the study subjects' intensity of pain accord- vention among the both groups $(p=.000)$, where it was ing to affective pain response. It was apparent that pain relieved after intervention among $70 \% \& 15 \%$ of them reintensity was statistically significant before and after inter- spectively. It was also statistically significant between the 
two groups before intervention ( $p=.054$ ), where $60 \%$ of the massage group experienced strong pain, compared to $35 \%$ of the warm application group. In addition, pain intensity was statistically significant between the two groups after inter- vention $(p=.000)$, where a sizeable proportion $(70 \%)$ of the former group experienced no pain, compared to only (15\%) of the latter group.

Table 9. Number and percent distribution of the study subjects according to their intensity of pain using affective pain response

\begin{tabular}{|c|c|c|c|c|c|c|c|c|c|}
\hline \multirow{3}{*}{$\begin{array}{l}\text { Severity of } \\
\text { pain }\end{array}$} & \multicolumn{4}{|c|}{ G1 (40) (Massage group) } & \multicolumn{4}{|c|}{ G 2 (40) (Warm application group) } & \multirow{3}{*}{$\mathbf{F} / \chi^{2}(P)$} \\
\hline & \multicolumn{2}{|c|}{$\begin{array}{l}4 \text { hrs after operation } \\
\& \text { before intervention }\end{array}$} & \multicolumn{2}{|c|}{$\begin{array}{l}6 \text { hrs after operation } \& \\
\text { after intervention }\end{array}$} & \multicolumn{2}{|c|}{$\begin{array}{l}4 \text { hrs after operation } \\
\& \text { before intervention }\end{array}$} & \multicolumn{2}{|c|}{$\begin{array}{l}6 \text { hrs after operation } \\
\text { \& after intervention }\end{array}$} & \\
\hline & $\mathbf{N}$ & $\%$ & $\mathbf{N}$ & $\%$ & $\mathbf{N}$ & $\%$ & $\mathbf{N}$ & $\%$ & \\
\hline None & 0 & 00.00 & 28 & 70.00 & 0 & 00.00 & 6 & 15.00 & \multirow{4}{*}{$\begin{array}{l}\text { Before } \\
\text { intervention } \\
9.263(.054)^{*} \\
\text { After } \\
\text { intervention }\end{array}$} \\
\hline Mild & 2 & 05.00 & 12 & 30.00 & 0 & 00.00 & 22 & 55.00 & \\
\hline Moderate & 14 & 35.00 & 0 & 00.00 & 24 & 60.00 & 12 & 30.00 & \\
\hline Strong & 24 & 60.00 & 0 & 00.00 & 14 & 35.00 & 0 & 00.00 & \\
\hline Unbearable & 0 & 0.00 & 0 & 00.00 & 2 & 05.00 & 0 & 00.00 & $29.176(.000)^{*}$ \\
\hline $\mathrm{F} / \chi^{2}(P)$ & \multicolumn{4}{|c|}{$73.143(.000)^{*}$} & \multicolumn{4}{|c|}{$48(.000)^{*}$} & \\
\hline
\end{tabular}

Note. $\chi^{2}(P)$ : Chi-Square Test $\& P$ for $\chi^{2}$ Test; $\mathrm{F}(P)$ :Fisher Exact test $\& P$ for F Test; ${ }^{*}$ : Significant at $p \leq .05$.

\section{Discussion}

Laparoscopic surgery is quickly turning into the gold standard for treatment of uncomplicated symptomatic abdominal pathologies; Gynecologic laparoscopic procedures are frequently associated with shoulder pain that may greater discomfort to the women than the pain at the site of incision. Reliving of shoulder pain is an essential goal of gynecological nurse. Shoulder Pain control can be practically accomplished by the use of pharmacological and non-pharmacological methods. ${ }^{[1,6]}$ Among the non-pharmacological approaches to relief pain is the use of effleurage massage and warm application.

The result of the present study revealed that both of massage and warm compresses groups were matching in almost all of their socio-demographic characteristics, menstrual history and reproductive history. This was quite expected since the study participants attending EL-Shatby Maternity University Hospital are almost from the same socio-demographic class. Assessment of laparoscopic data in the current study included: causes, duration, factors increasing pain and factors decreasing pain. No significant difference was observed among both groups. This homogenous profile of the both groups may help understand and/or justify the relevance of the forthcoming results of the current study. It may also provide logic rational in relation to the possible positive effect of massage and warm compresses on shoulder pain intensity.

\subsection{Shoulder pain intensity}

The present study revealed that pain intensity by using visual analog scale was statistically significant difference before and after the interventions among the massage and warm application groups. Such similarities among the result of the current study can be attributed to what is elicited in the literature about the possible positive physiological and psychological effects of massage to reduce pain intensity. These include: improvement of circulation, relaxation of muscles stimulation of the lymphatic system, speeding up the elimination of waste products, helping digestion, inducing sleep, enhancing mental and physical relaxation, encouraging the release of emotional tension and thereby encouraging communication. Accordingly, it enhances women's ability to cope with pain in general. ${ }^{[37]}$ Also according to the literature in this respect warm application has a sedative effect through vasodilatation of the blood vessels, increasing blood flow to the area, promoting relaxation and consequently reducing pain intensity. ${ }^{[23]}$

On the other hand, when comparing the two nonpharmacological modalities used in the current study, it can be observed that although the massage had reduced pain intensity among a sizeable proportion of the massage group (70\%) compared to only $25 \%$ of the warm application group. This result suggests that the duration of massage in this study, was probably enough to see the para-sympathetic response and functioning of endocrines which stimulate the secretion of endorphins and can decrease pain severity in women.

Because the research carried out in this area is very few, we will use the researches that used the same interventions on other types of pain, The finding of the present study is in line with Allam (2017), who reported that the application of lumbo-sacral massage had a more statistically significant difference in decreasing labor pain than warm bag application. ${ }^{[38]}$ 


\subsection{Physiological pain responses}

The present study reveals that the physiological response to pain was apparently related to the application of massage \& warm application. Generally speaking, both pain intensity and its physiological parameters are two sides of one coin. Whereas, when pain intensity decreases, the physiological parameters (blood pressure, heart rate, respiratory rate) also decrease and vice versa. This mechanism is based on the fact that the stimulation of the central nervous system secondary to pain \& or stress is manifested in such physiological changes. ${ }^{[39]}$

The present study revealed that a statistically significant difference in maternal pulse rate between the two groups before intervention $(p=.001)$. Where the mean pulse for the massage group was $90.55 \pm 8.092$, compared to $84.8 \pm 6.505$ for the warm application group. A statistically significant difference was also found between the two groups after intervention $(p=.002)$, where the mean pulse for the massage group was $88.7 \pm 6.227$, compared to $83.9 \pm 7.175$ for the warm application group.

This current finding is similar to the study of Nourian et al. (2016), they found that massage reduced hospitalization anxiety, pulse rate and blood pressure. They recommended that nurses can use massage to reduce anxiety in school-age children at hospital since it has no side-effects and is easily applicable. ${ }^{[40]}$

However, this same result is dissimilar to the study of Hablas R 2011 (doctorate dissertation) titled "Efficacy of basil essential oil on Pain intensity during the first stage of labor". The researcher concluded that the use of essential oil massage had no effect on heart rate. ${ }^{[1]}$

On the other hand, in relation to blood pressure, the present study shows that the mean value of systolic blood pressure was statistically significant different between the massage group before and after intervention $(p \leq .007)$. Regarding diastolic BP, the relationship among the warm application group before and after intervention was highly statistically significant $(p \leq .0001)$, while it was statistically significant among the massage group $(p=.023)$. Also, it was statistically significant after intervention among the massage and warm application groups $(p=.050)$.

This current finding is in harmony with the study of Kanjirathinkal F.(2011),they concluded that there was a statistically significant difference in physiological parameters of relaxation following effleurage back massage as measured by temperature, blood pressure and respiratory rate. ${ }^{[42]}$

This is also in line with the study of Givi (2013), who found that the mean systolic and diastolic blood pressure were sig-

Published by Sciedu Press nificantly lower in comparison with the control group $p=$ .001. Evaluation of durability of the massage effects on blood pressure also indicated that 72 hours after finishing the study, still there was significant difference between the test and control groups in systolic and diastolic blood pressure where $p=.001 .^{[43]}$

Such finding may provide an evidence for the possible effect of massage on the reduction of shoulder pain. The rational for this is based on the physiological link between pain and the blood pressure. Where pain stimulates the sympathetic nervous system resulting in an increase in the secretion of catecholamine. Such stimulation causes vasoconstriction and a subsequent rise in blood pressure. Accordingly, when the pain decreases blood pressure also decreases. Furthermore, massage provides relaxation and therefore is able to reduce blood pressure through decreasing sympathetic activity and increasing parasympathetic activity. ${ }^{[4]}$

When talking about respiratory rate, a statistically significant difference was found between the warm application group before and after intervention $(p=.000)$. Such finding is in line with the relevant literature which indicates that massage therapy and warm bottle application develops respiratory muscles and helps increase oxygen intake by providing relaxation and easier breathing pattern. ${ }^{[45,46]}$

This may reflect the potential physiological effect of massage and warm application on respiratory rate. This probably due to two aspects. Firstly respiratory rate-as a physiological response to labor pains- usually increase as a result of the increase in the amount of oxygen available to the heart during pain or stress. Consequently, when the pain deceases the respiratory rate returns to normal rate. Secondly the use of two modalities is effective in restoring regular respiratory rate and decrease pain. ${ }^{[47]}$

In general-according to the relevant literatures- the effect of massage on vital signs in the present study was achieved because effleurage massage affects the Peripheral Nervous System (PNS) through somato-sensory stimulation of mechanoreceptors which is located within both the ectodermal tissue massage therapist's touch and the underlying mesoderm they manipulate. An influential theory proposes that a biological gating mechanism exists within the dorsal horn of the spinal cord where polysynaptic interferon prevents the impulse of smaller nerve fibers transmitting signals from pain receptors due to the stimulation of large afferent nerve fibers resulting in pain perception and consequently reducing physiological response due to relaxation for the body. ${ }^{[48]}$

The results of the present study showed that the pain inten- 
sity which is measured by (CPPRS) was statistically significant before and after management among the massage and warm application groups $(p=.000)$. It was also statistically significant between the two groups after intervention $(p=$ $.007)$, where a more than half of the massage group (55\%) experienced no pain, compared to only $20 \%$ of the warm application group. This finding is congruent with the study carried out by Sadat et al. (2016), they concluded that circular manual massage at lumbo-sacral region during the active phase of labor reduced labor pain efficiently. ${ }^{[49]}$

\subsection{Sensory description of shoulder pain response}

The pain rating index rank as measured by JPOMS (sensory part) in the present study supports the previous results The result of the present study shows that the pain intensity was statistically significant before and after intervention among the massage and warm application groups $(p=.000)$. It was also statistically significant between the two groups before and after intervention respectively $(p=.054 \& 0.000)$ where a more than three-fifths of the massage group (65\%) experienced no pain, compared to only $15 \%$ of the warm application group.

According to the literature review massage and warm bag application result in an increase of blood flow to the area or what is also known as vasodilatation. In addition, reduce pain by affecting on the central nervous system. It causes release of endorphins which abolish pain sensations in the brain. Stimulation of the mechanoreceptors by massage and warm application has been shown to enhance relaxation, reduce pain and muscle tension. ${ }^{[50]}$

Furthermore, the result of present study is in harmony with the study of Kozak A et al. (2017), they concluded that: most women are interested in non-pharmacological methods of pain relief during childbirth. The use of natural techniques reduces the intensity of labor pain. ${ }^{[51]}$

The current finding also corresponds with the study carried out by Fahami et al. (2011), the study indicated a significant decrease in pain intensity of the heat therapy group at the first stage and second stage of labor by comparing the two groups. They showed significant difference where $p<.001 .^{[52]}$

\subsection{Affective description of shoulder pain response}

The present study revealed that pain intensity was statistically significant before and after intervention among the massage and warm application groups $(p=.000)$. It was also statistically significant between the two groups before and after intervention respectively $(p=.054 \& .000)$ where a sizeable proportion of the massage group (70\%) experienced no pain, compared to only $15 \%$ of the warm application group.

This finding agrees with Adam et al. (2012), they found that 62 a large proportion of women in the study achieved a vaginal delivery independent of fear of childbirth $(89.1 \%$ of women with and $93.2 \%$ of women without fear of childbirth). They concluded that the duration of labor was longer in women with fear of childbirth than in women without such fear. ${ }^{[53]}$

This finding is congruent with the relevant literature which states that women who perceive touch and massage during labor as positive intervention have less pain, anxiety and need for pain medication. While warm bag application acts through the heat receptors switch to the site of pain. These heat receptors, in turn block the effect of chemical messengers that cause pain and subsequently reduce fear and anxiety. ${ }^{[54]}$

The pain rating index rank as measured by JPOM sensory and affective response in the present study supports the previous results. As massage seems to be effective in reducing shoulder pain intensity immediately after intervention; the present finding agrees with the study carried out by Sethi et al. (2017), they concluded that the back massage had an impact on pain level. Therefore, it was demonstrated that back massage was effective to reduce the level of pain. ${ }^{[55]}$

\section{Conclusion}

Based on the findings of the present study, it can be concluded that the hypothesis (1) is accepted and hypothesis (2) is rejected because the shoulder massage effleurage and warm bag application have eventually lead to reduction of shoulder pain. However, the shoulder effleurage massage seems more effective than warm bag application as a nonpharmacological modality of pain relief.

\section{Recommondation}

Based on the findings of the present study, the following recommendations are suggested: 1) The curricula of basic nursing education as well as continuing education should entail the non-pharmacological management of shoulder pain. 2) Effleurage massage and warm bottle should be recommended in hospital protocols for management of shoulder pain.

3) Implement in service training for the nurses especially in non pharmacological method to relieve pain.

4) Further researchers are needed to:

- The effect of effleurage and warm bottle application on other pain encountered during the maternity cycle.

- Replication of the present study at different settings and among different samples.

\section{CONFlicts OF INTEREST Disclosure}

The authors declare that there is no conflict of interest. 


\section{REFERENCES}

[1] Tsai HW, Chen YJ, Ho CM, et al. Maneuvers to decrease laparoscopyinduced shoulder and upper abdominal pain: a randomized controlled study. Arch Surg. 2011; 146: 1360-6. PMid:22184293 https://doi.org/10.1001/archsurg. 2011.597

[2] Dixon JB, Reuben Y, Halket C, et al. Shoulder pain is a common problem following laparoscopic adjustable gastric band surgery. Obes Surg. 2005; 15: 1111. PMid:16197781 https://doi.org/10.138 1/0960892055002149

[3] Johnson N, Barlow D, Lethaby A, et al. Surgical approach to hysterectomy for benign gynaecological disease. The Cochrane Database of Systematic Reviews. 2006. https : //doi .org/10.1002/1465 1858. CD003677. pub2

[4] Kluivers KB, Johnson NP, Chien P, et al. Comparison of laparoscopic and abdominal hysterectomy in terms of quality of life: a systematic review. Eur J Obstet Gynecol Reprod Biol. 2008; 136: 38. PMid:18063290 https://doi.org/10.1016/j.ejogrb. 200 7.06 .004

[5] Taş B, Donatsky AM, Gögenur I. Techniques to reduce shoulder pain after laparoscopic surgery for benign gynaecological disease: systematic review. Gynecol Surg. 2013; 10(3): 169-75. https: //doi.org/10.1007/s10397-013-0791-7

[6] Phelps P, Cakmakkaya OS, Apfel CC, et al. A simple clinical maneuver to reduce laparoscopy-induced shoulder pain. Obstet Gynecol. 2008; 111(5): 1155-60. PMid:18448749 https ://doi.org/10.1 097/AOG.0b013e31816e34b4

[7] Chang SH, Lee HW, Kim HK, et al. An evaluation of perioperative pregabalin for prevention and attenuation of postoperative shoulder pain after laparoscopic cholecystectomy. Anesth Analg. 2009; 109(4): 1284-6. PMid:19641054 https://doi.org/10.1213/ane.0b01 3e3181b4874d

[8] Dixon JB, Reugen Y, Halket C, et al. Shoulder pain is a common problem following laparoscopic adjustable gastric band surgery. Obes Surg. 2005; 15: 1111-7. PMid:16197781 https ://doi.org/10.1 381/0960892055002149

[9] Dutta DC. Textbook of gyneacology, 5th edition.India:NewCenteralBookAgency. 2008; 55-60.

[10] Kojima Y, Yokota S, Ina H. Shoulder pain after gynaecological laparoscopy caused by arm abduction. Eur J Anaesthesiol. 2004; 21(7): 578-579. https://doi.org/10.1097/00003643-20040 7000-00017

[11] Fredman B, Jedeikin R, Olfsanger D. Residual pneumoperitoneum: a cause of postoperative pain after laparoscopic cholecystectomy. Anesth.Analg. 1994; 79: 152-154. https://doi.org/10.1213/ 00000539-199407000-00028

[12] Phelps P, Cakmakkaya OS, Apfel CC, et al. A simple clinical maneuver to reduce laparoscopy-induced shoulder pain: a randomized controlled trial. ObstetGynecol. 2008; 111: 1155-60. PMid:18448749 https://doi.org/10.1097/AOG.0b013e31816e34b4

[13] Jasim S, Issam M, Salam NA. The efficacy of active gas suctioning to decrease the residual co2for preventing post laparoscopic cholecystectomy shoulder pain. Bas J Surg. 2012; 18.

[14] Uen YH, Chen Y, Kuo CY, et al. Randomized trial of low-pressure carbon dioxide-elicited pneumoperitoneum versus abdominal wall lifting for laparoscopic cholecystectomy. J Chin Med Assoc. 2007; 70: 324-330. https : //doi .org/10.1016/S1726-4901 (08)700 13-3

[15] Ng A, Swami A, Smith G, et al. Is intraperitoneal levobupivacaine with epinephrine useful for analgesia following laparoscopic cholecystectomy? A randomized controlled trial. Eur J Anaesthesiol. 2004; 21: 653-657. https://doi.org/10.1097/00003643-2004080 00-00011

Published by Sciedu Press
[16] Esmat ME, Elsebae MM, Nasr MM, et al. Combined low pressure pneumoperitoneum and intraperitoneal infusion of normal saline for reducing shoulder tip pain following laparoscopic cholecystectomy. World J Surg. 2006; 30(11): 1969-73. PMid:17043939 https ://doi.org/10.1007/s00268-005-0752-z

[17] Suginami R, Taniguchi F, Suginami H. Prevention of post laparoscopic shoulder pain by forced evacuation of residual CO2. Journal of the Society of laparoendoscopic Surgeons. 2009; 56-59.

[18] Khoo CK. A prospective randomized controlled trial of multimodal perioperative management protocol in patients undergoing elective colorectal resection for cancer. Ann Surg. 2007; 245(6): 867-72. PMid:17522511 https://doi.org/10.1097/01.sla.0000259 219.08209 .36

[19] Snow S, Taylor K, Carpenter J. rapid midwifery. 1st edition. Wiley black well: congress. 2016; 53:54.

[20] Arslan S, Çelebioğlu, A. Postoperatif Ağrı Yönetimi ve Alternatif Uygulamalar. International Journal of Human Sciences. 2004; 1(1): $1-7$.

[21] Sinha A. principle and practice of therapeutic massage. New Delhi. Jypee. 2001; 108-9.

[22] Dryden T, Moyer C. Massage therapy. Integrating research and practice. USA. 2012; 85.

[23] Five basic massage moves and effects. Available from: http://expertbeautyspa.wordpress.com/.../s-bas ics-massages-move

[24] Gillman C. The healing therapies Bible: Gods field Bible. Hachette UK. 2016; 216-17.

[25] Domenioo G. Beard's massage: principle and practices of soft tissue manipulation. 5th edition. Philadelphia. Saunders Elsevier. 2003; 30.

[26] Other tools for labor: parent resources network. 2019. Available from: http://www.parentresourcenetworking.org/o ther-tool-forlabor/

[27] Simancek J. Deep tissue massages treatment. USA. Mosby company. 2013; 27.

[28] Gerrain M. Milady standard cosmetology. USA. Cengage Learning. 2012; 725.

[29] McCauley P. Medical massage care's. Therapeutic massage national certification exam study guide. Congress. Washington. 2005; 65.

[30] Rakel D. Integrative Medicin.3rd edition. USA. Elsevier Company. 2012; 488.

[31] Sakala C, Maureen P. Evidence - Based Maternity Care. What it is and What it can achieve. Available from: http://childbirthco nnection.org/...evidance-based-mater

[32] Shin HY, Kim SH, Lee YJ, et al. The effect of mechanical ventilation tidal volume during pneumoperitoneum on shoulder pain after a laparoscopic appendectomy. Surg Endosc. 2010; 24: 2002. PMid:20135168 https ://doi.org/10.1007/s00464-010-089 5-3

[33] Ludington E. Statistical analysis of total labor pain using visual analogue scale and application of analgesic effectiveness during child birth. International Anesthesia, Research Society Journal. 1998; 87(7): 723-7. PMid:9728862 https ://doi.org/10.1097/0000 0539-199809000-00045

[34] Deborah B. the measurement of clinical pain. Journal of Nursing Research. 1984; 33(3): 152-56. https://doi.org/10.1097/00 006199-198405000-00007

[35] Walsh L. Midwifery community based care during child bearing years. Philadelphia, W.B. Saunders Company; 2001; 100-10.

[36] Johansson F. Measurement of pain: the psychometric properties of the Pain-O-Meter, a simple, inexpensive pain assessment tool that could change health care practices. J Pain Symptom Manage. 1996; 12: 172-81. https://doi.org/10.1016/0885-3924(96)00128-5 
[37] Ball A, Medforthy J, stables S. Oxford handbook of midwifery. 3rd edition. Congress library. Oxford University. 2017; 90-4.

[38] Allam T. Effect of lumbo-sacral massage versus warm application on pain intensity during the active phase of the first stage of labor. 2017; 10-15.

[39] A dams R, White B, Beckett C. The Effects of Massage Therapy on Pain Management in the Acute Care Setting. 2010; 3(1): 4-11. https://doi.org/10.3822/ijtmb.v3i1.54

[40] Nourian M, Jalalodini A, Saatchi K, et al. The effectiveness of slow stroke back massage on hospitalization anxiety and physiological parameter in school age. 2016; 18(11). PMid:28210499 https://doi.org/10.5812/ircmj . 36567

[41] Hablas R. Efficacy of basil essential oil on Pain intensity during the first stage of labor. 2011; 17-19.

[42] Kanjirathinkal F. Study to evaluate the effectiveness effleurage back massage on physiological and psychological parameters of relaxation among bedridden patient. 2011; 9-11.

[43] Givi M. Durability of effect of massage therapy on blood pressure. 2013; 4(5): 511-516

[44] Leah L. Evidence for physiological management of active phases of first stage of labor. Midwifery and Women Health Journal. 2007; 52(3): 207-75. PMid:17467587 https://doi.org/10.1016/j . jmwh. 2006.12.009

[45] Physiological effect of massage therapy. 2017.

[46] A gren A. The labor tactile massage and severe nausea and vomiting during pregnancy women's experience. 2006; 20(2): 169-76.
PMid:16756522 https : //doi.org/10.1111/j.1471-6712.20 $06.00394 . \mathrm{x}$

[47] Lowdermilk D, Perry S, Cashion K, et al. Maternity women and health care. 11th edition. China. Elsevier. 2016; 382: 8 .

[48] Jamsek M. Physiological effects of Swedish massage: A preliminary analysis of the fundamental techniques. Available from: https: //www.ncbi.nIm.nih.gov/pmc/articles/pmc3091428

[49] Sadat H, forugh F, Maryam H, et al. Impact of manual massage on intensity and duration of pain at first phase of labor pain in primigravida women. 2016; 1(4).

[50] Sittner B, Hudson D, Grossman C. Adolescent perception of pain during labor. 1998; 7(1): 82-93. PMid:9526316 https://doi .or $\mathrm{g} / 10.1177 / 105477389800700107$

[51] Kozak A, Klauesk L, Beata D, et al. Non- pharmacological of pain relief in labor in the openion puerperal. 2017; 1(1): 1-4.

[52] Fahami F, Behmanesh M, Ashouri E. Effect of heat therapy on pain severity in primigravida women. 2011; 16(1): 113-116.

[53] Adam S, Gran M. Fear of childbirth and duration of labor: A study of 2206 women with intended vaginal delivery. 2012.

[54] Hot water bottle really dose ease period pains.

[55] Sethi D, Barnabas S. Pre-experimental study to evaluate the effectiveness of back massage among pregnant women in the first stage of labor pains admitted in labor room of a selected hospital, Ludhiana, Punjab, India. 2017; 6(1). https : //doi .org/10.18203/2320-1 770.ijrcog20164636 